\title{
MONITORING THE FLOOD PULSES IN THE EPIPHREATIC ZONE OF KARST AQUIFERS: THE CASE OF REKA RIVER SYSTEM, KARST PLATEAU, SW SLOVENIA
}

\author{
SPREMLJANJE POPLAVNIH VALOV V EPIFREATIČNI CONI \\ KRAŠKEGA VODONOSNIKA: PRIMER REKE REKE, KRAS, \\ JZ SLOVENIJA
}

\author{
Franci GABROVŠEK ${ }^{1} \&$ Borut PERIC ${ }^{2}$
}

\begin{abstract}
UDC 556.3 (497.4-14)

Franci Gabrovšek \& Borut Peric: Monitoring the flood pulses in the epiphreatic zone of karst aquifers: The case of Reka river system, Karst plateau, SW Slovenia

The Reka river sinking into Škocjan caves (Škocjanske jame) is the main allogenic input into the aquifer of Classical Karst. So far the subsurface flow of the Reka river between Škocjan caves and the spring of Timava in Italy has been reached in five caves. Two were recently discovered in Slovenia. Continuous logging of water levels and temperatures in four of these caves was established in spring 2005. The paper presents and briefly discusses the first results obtained in three of them. The results are indicating a fast passage of a flood wave along a well developed conduit system.
\end{abstract}

Key words: karst hydrology, aquifer, flood pulse, Reka, Kras, Slovenia.
Izvleček

UDK 556.3 (497.4-14)

Franci Gabrovšek \& Borut Peric: Spremljanje poplavnih valov $v$ epifreatični coni kraškega vodonosnika: Primer reke Reke, Kras, JZ slovenija

Reka Reka, ki ponika v Škocjanske jame, je najpomembnejši alogeni vir, iz katerega se napaja kraški vodonosnik. Doslej so med Škocjanskimi jamami in izviri Timave v Italiji našli pet jam, kjer je mogoče priti do podzemnega toka Reke. Dve so pred kratkim odkrili v Sloveniji. Pomladi leta 2005 se je začelo stalno spremljanje nivoja in temperature vode $\mathrm{v}$ štirih od teh jam. Članek predstavlja in na kratko obravnava prve rezultate, pridobljene na treh merilnih mestih. Rezultati kažejo na hitro potovanje poplavnega vala po dobro razvitem sistemu kraških kanalov.

Ključne besede: kraška hidrologija, vodonosnik, poplavni val, Reka, Kras, Slovenija.

\section{INTRODUCTION}

The Kras (Classical Karst) plateau has been attracting researchers for more than a century. Its aquifer is as complex as a karst aquifer can get. A more than $300 \mathrm{~m}$ deep vadose zone, huge underground cavities, all possible flow regimes, complex recharge and discharge conditions and complex evolution, enough to believe that the system is far from being resolved. This paper presents the first results of an ongoing effort to put a new stone into the puzzle of the aquifer of Kras.

Fig. 1 presents a generalized map and a cross-section of the Kras plateau and its surroundings. It shows the main geological formations, caves with the active underground flow and the measurement points presented in this paper.

Kras belongs to the Adriatic-Dinaric tectonic plate in the region of the Outer Dinarids (Kranjc, 1997). The folds sink towards NW under Soča alluvium. The same direction is also followed by the main draining conduits from SE of the plateau. The area is mostly composed of Cretaceous and Tertiary carbonate sediments.

The depth of the unsaturated zone reaches more than $300 \mathrm{~m}$. Many caves, remains of an old drainage network, can be found along its complete vertical profile.

${ }^{1}$ Karst Research Institute, ZRC SAZU, Titov trg 2, SI-6230 Postojna, Slovenia

${ }^{2}$ Park Škocjanske jame Public Agency, Škocjan 2, SI-6215 Divača, Slovenia

Received / Prejeto: 20.06.2006 


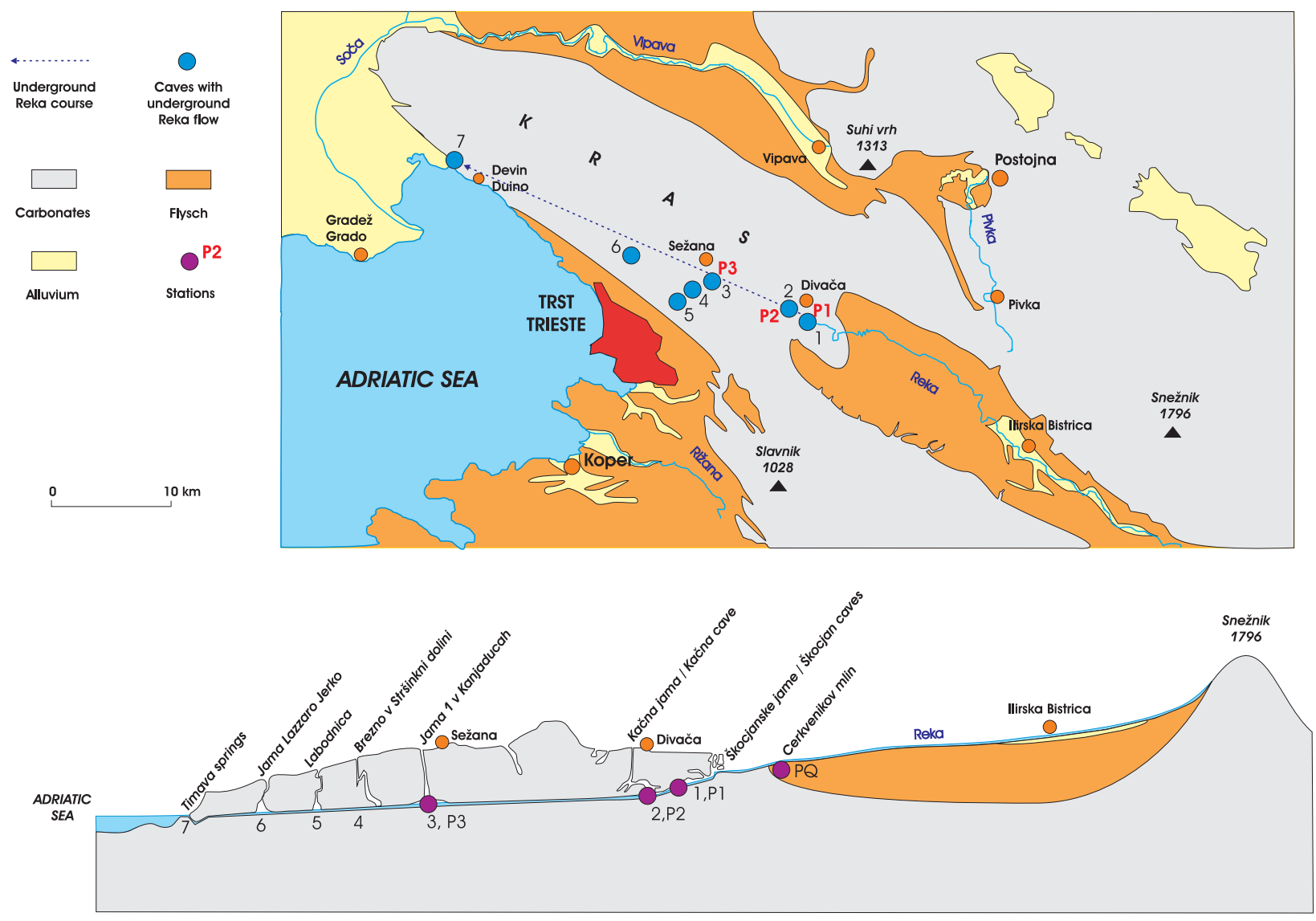

Fig. 1: Simplified map and cross-section of the Kras plateau with main geological formations, caves and measurement points presented in this study.

Below the piezometric surface, the structure of the aquifer is largely unknown. An indicator of a well developed conduit system was a sudden collapse in the Reka stream near Gornje Vreme in 1980, at the flysch-limestone contact, where around $1 \mathrm{~m}^{3} / \mathrm{s}$ still disappears underground (Brilly et al., 2002).

The focus of our study is epiphreatic zone, characterized by a high flow variability of the Reka river which is the main allogenic input to the aquifer. The river flows about 50 kilometers on impermeable flysch rocks, continues for another 7 kilometers as a surface flow on a limestone terrain, and starts its underground course at Škocjan caves. It emerges at the Timavo springs in Trieste Bay. The air distance between Škocjan caves and springs of Timavo is around $33 \mathrm{~km}$. Based on the data of the Environmental Agency of the Republic of Slovenia for the period 1961-1990, the average discharge of the Reka River is $8.26 \mathrm{~m}^{3} / \mathrm{s}$. The ratio between low and high waters reaches 1 to 1700 with the maximum measured discharge $305 \mathrm{~m}^{3} / \mathrm{s}$, and minimum $0.18 \mathrm{~m}^{3} / \mathrm{s}$. The springs of Timavo have an average discharge of $30.2 \mathrm{~m}^{3} / \mathrm{s}$. Beside main spring, the aquifer discharges through the many other smaller springs in the vicinity, many of which are bellow the sea surface.

Efforts to reach Reka between Škocjan caves and the springs of Timavo have long history (Kranjc, 1997). At the moment we know five caves leading to the active subsurface flow: Kačna cave and Labodnica/Grotta di Trebiciano are well known and have already been thoroughly investigated. Recently, three additional caves were pushed down to the depths of active Reka flow: Lazzaro Jerko in Italy; Jama $1 \mathrm{v}$ Kanjaducah and Brezno v Stršinkni dolini in Slovenia. The river has also been reached through Brezno 3G, which turned out to be another entrance of Kačna cave.

In Škocjan caves and Kačna cave it is possible to follow several kilometers of the underground river, while only small fragments are accessible in other caves as the confining siphons are not far apart, therefore further exploration is left to cave divers.

For more information on geology, speleology, hydrogeology and history of exploration and research of Classical Karst and its aquifer refer to (Cucchi et al., 2000; Galli, 1999; Kranjc, 1997; Mihevc, 2001). 
Cuchi and Zinni (2002) reported on the continuous monitoring of physical parameters of the subsurface Reka flow. They have measured level, temperature and specific electric conductivity in Škocjan caves, Grotta di Trebiciano/Labodnica, Lazzaro Jerko and Timavo springs. Based on more than 100 flood events, a distinction was made between three principal types of flood waves, characterized by the presence or absence of inflow from the sources that feed the Timavo river system: namely the Reka River, Brestovica basin and Soča-Vipava rivers basin. The temperature and conductivity changes between Škocjan caves, Labodnica/Trebiciano and Lazzaro Jerko cave indicate that the underground flow is fast (even more than $800 \mathrm{~m} / \mathrm{h}$ ) and continuous. Their results indicate a "direct drainage" along Škocjan-Labodnica/ Trebiciano-Lazzaro Jerko. They proposed that the aquifer of Classical Karst is at the $3^{\text {rd }}$ state of the Ford-Ewers's speleogenetic model (Ford \& Ewers, 1978).

\section{OBSERVATION POINTS}

Except in Škocjan caves, the underground flow of Reka is not easy accessible. To reach it one must descend between 250 and $330 \mathrm{~m}$ down vertical shafts and steep galleries.

New entrances are rarely found. During the flood events when the water rises and squeezes the air from the voids and fractures, an intense airflow can be detected at some spots at the surface. These are the spots where cavers start following narrow leads through the vadose zone and hope to enter an easy passage to the river. Normally it takes years of digging and climbing to succeed. Except in Škocjan caves and Kačna cave, all the discoveries have been done this way.

Between February and October 2005, data loggers were placed in Škocjan caves, Kačna cave, Jama 1 v Kanjaducah and Brezno v Stršinkni dolini. Data from the first three caves have been retrieved so far and are presented
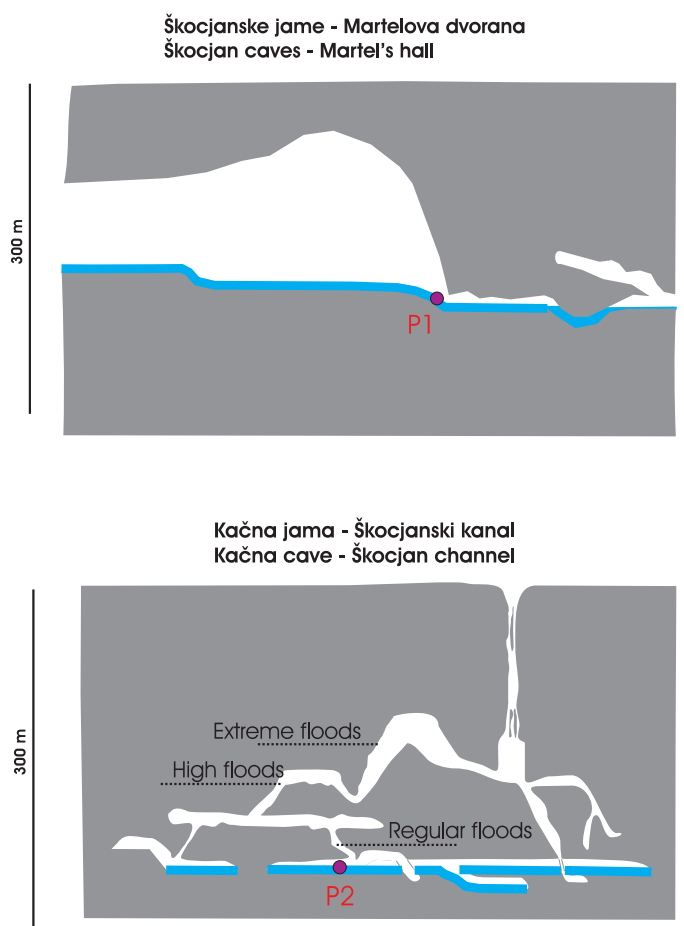

in this paper. The distance between Škocjan caves and Kačna cave is about two kilometres. The direct distance from Kačna cave to Jama $1 \mathrm{v}$ Kanjaducah is about seven kilometers (see Fig. 1).

The instruments were fixed to the underground river banks. In Škocjan caves and Kačna cave the micro location was chosen so that the instruments cannot be damaged by larger pieces of flotsam.

Fig. 2 shows simplified sketches of the caves with the positions of measurement points. In Škocjan caves it was fixed at Martel's lake (P1) at the end of 2.2 millions $\mathrm{m}^{3}$ large Martel's chamber, in Kačna cave at rapids in Škocjanski kanal passage (P2), in Kanjaduce (P3) and Brezno v Stršinkni dolini it is located at terminal sumps at the end of the caves.

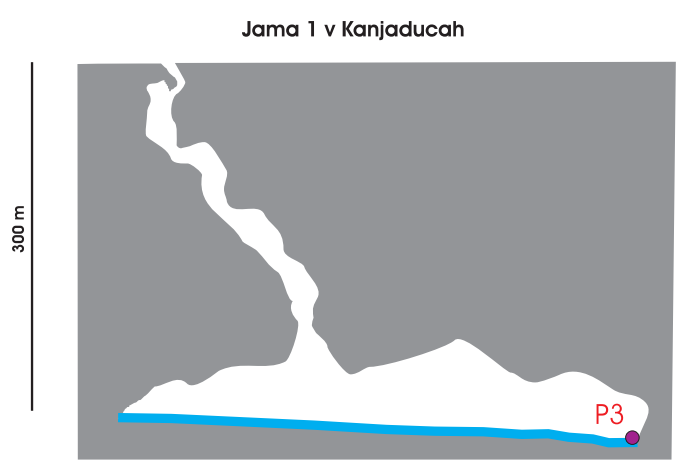

Fig. 2: Simplified sketches of the caves with positions of the measuring points. Flood levels based on flotsam occurrence (Mihevc, 2001) are marked in Kačna cave. Maps of Škocjan caves and Kačna cave were obtained from the Karst Research Institute archive and Slovenian cave cadastre. Map of Jama $1 v$ Kanjaducah was obtained from the web site of Sežana caving club (http://www.brlog.net/jds/kanjaduce.htm). 


\section{INSTRUMENTS}

To log water level and temperature we use TD Diver produced by Van Essen, a Schlumberger company, Holland (Fig. 3). Instruments measure and record pressure and temperature. Recently we have introduced instruments (CTD Diver) which additionally log specific electric con- range of $100 \mathrm{~m}$. Precision of the level measurements is $0.1 \%$ of the full range, i.e. $10 \mathrm{~cm}$ in our case. Precision of temperature sensor is $0.1^{\circ} \mathrm{C}$. Data from the instrument can be retrieved to computer via optical bridge as shown in Fig. 3.
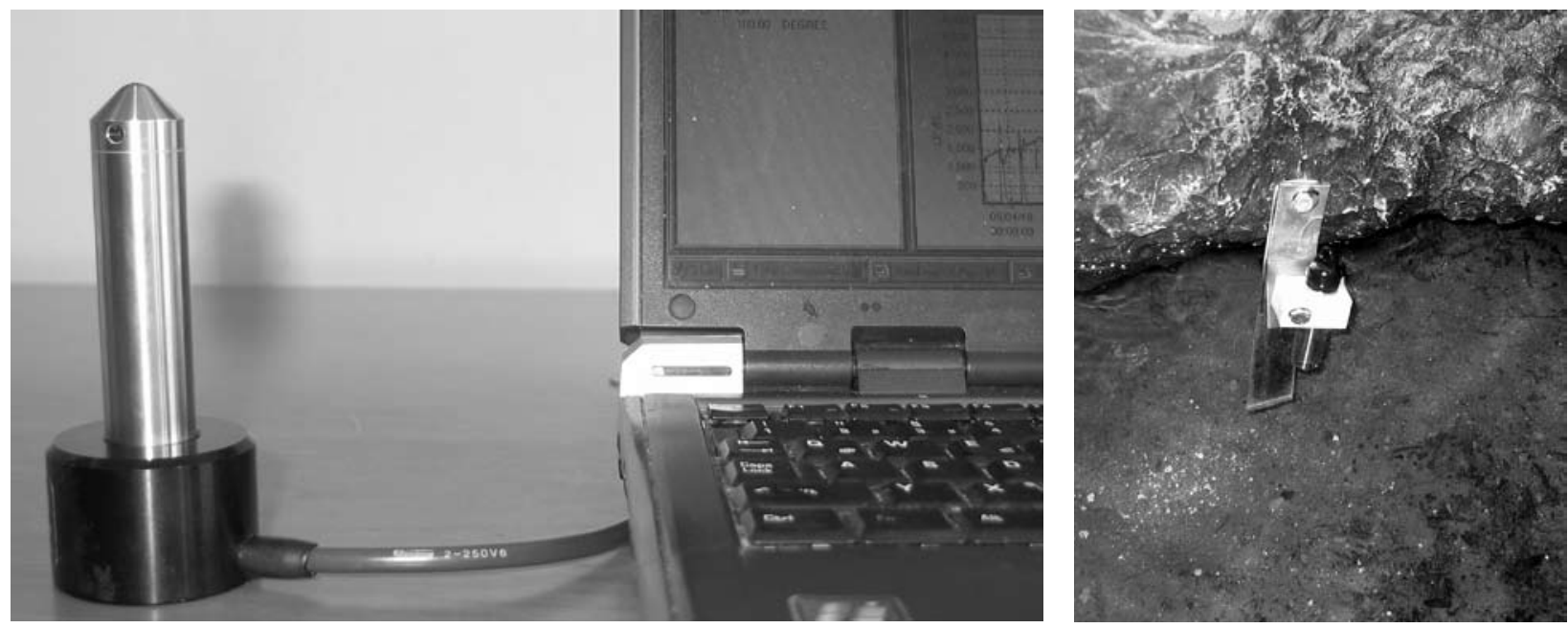

Fig. 3: Datalogger in the office, connected to the computer via optical reader (left) and fixed to the wall of the terminate lake of Jama 1 $v$ Kanjeducah (P3) (right).

ductivity. The instruments are autonomous, the autonomy being guaranteed by the life span of internal batteries which is 8-10 y (depending on measurement frequency) and internal memory which can hold up to 24000 readings (TD). They are easy to program by the enclosed software. The sampling interval is between 5 seconds and 99 hours, sampling can be linear, logarithmic or event based. We used the instruments with the measurement
The pressure sensor is a ceramic transducer therefore the measured level value is the sum of water and air pressure converted to a water column. For small level fluctuation (e.g. decimeter scale), the levels should be compensated with the barometric measurements of the surrounding atmosphere. Since we are interested in the large scale oscillations, we have not done that.

\section{RESULTS AND DISCUSSION}

The main input to our system is the sinking stream of Reka therefore the flow hydrograph at the station Cerkvenikov mlin provided by Slovene Environmental Agency is taken as an input data into the system. As mentioned, there is a considerable leakage from Reka into the karst aquifer before to the arrival at Škocjan caves which is neglected in the course of discussion. One should also consider the dispersed and concentrated input to the conduits from the karst surface along the entire pathway. The latter was reported by divers who conducted research in the terminal siphons of Škocjan caves.
Results for the entire period are shown in Fig. 4. During the spring, four flood events with the level rise of several meters occurred. A dry period followed with some small scale events in August.

Fig. 5 presents larger events in a weekly time window. Upper graphs show levels, whilst lower graphs their time derivatives, i.e. rising and dropping rates in $\mathrm{m} / \mathrm{h}$. Top axes give dates, bottom axes give time in hours elapsed since the recording started in Škocjan caves (February $\left.18^{\text {th }}, 2005\right)$. Note that the flow at Cerkvenikov mlin is in units of $10 \mathrm{~m}^{3} / \mathrm{s}$. 


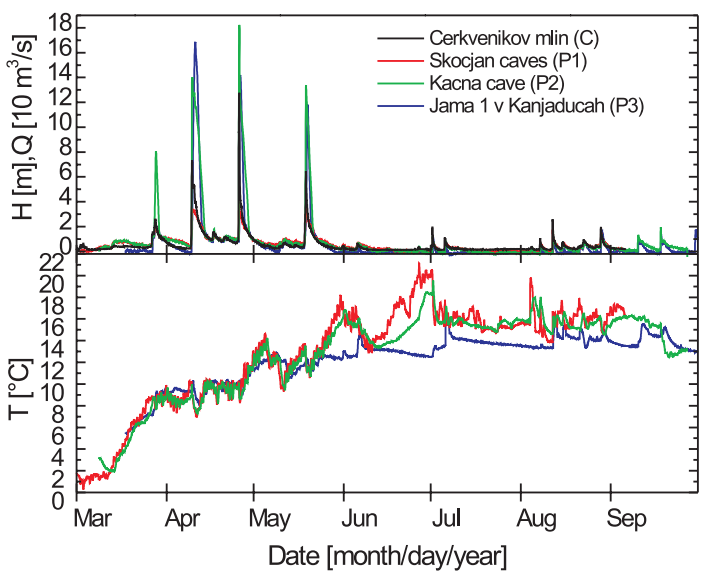

Fig. 4: Upper figure presents flow rates at Cerkvenikov mlin $(C)$ and levels at points P1-P3 during the whole period. Lower figure shows temperatures at measurement points. Colour code is valid for both graphs.
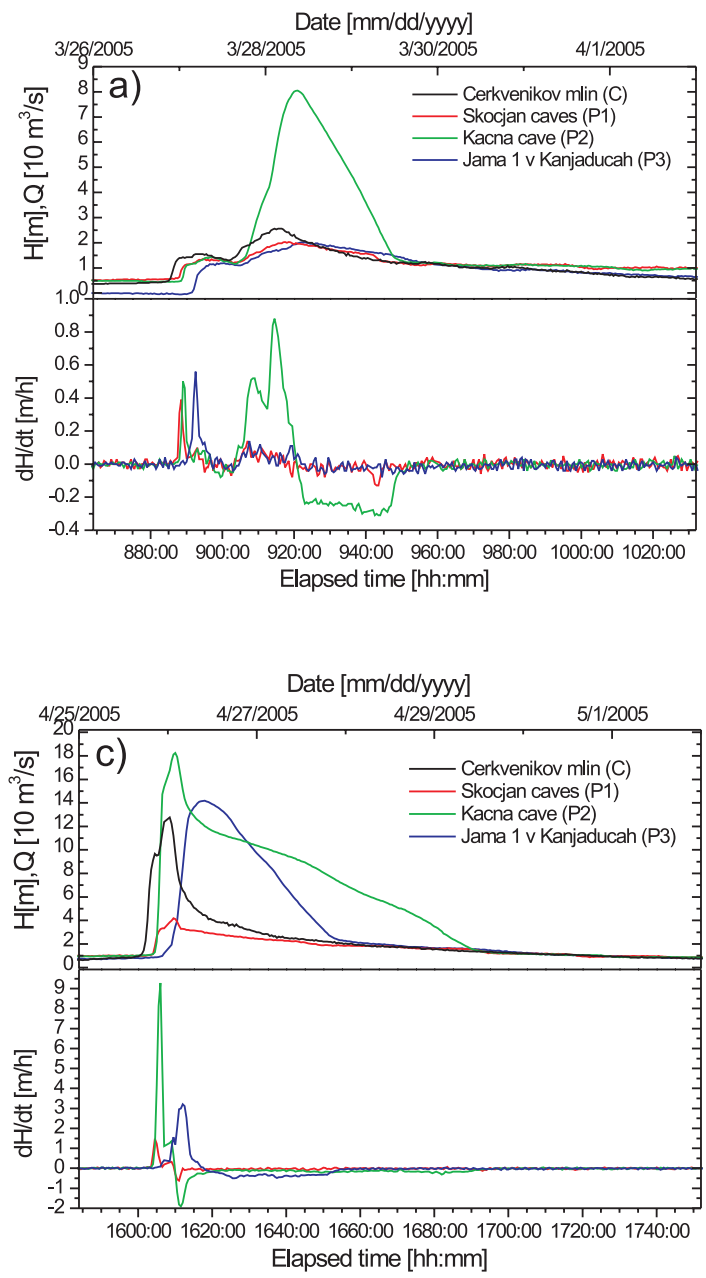

First event (Fig. 5a), starting on March $27^{\text {th }}$, is compiled of two flood pulses with time lag of a day with peak flow rates at 15 and $25 \mathrm{~m}^{3} / \mathrm{s}$ respectively. The level response to the first pulse was of similar magnitude in all three caves. Second pulse with $25 \mathrm{~m}^{3} / \mathrm{s}$ did not make a considerable difference in Škocjan caves (P1) and Kanjeduce (P3), yet the level in Kačna cave (P2) rose for almost 7 meters. Slow increase of the input flow resulted in a slow increase of the levels. In Kačna cave (P2) the rate of level increase reached $0.9 \mathrm{~m} / \mathrm{h}$.

Second event (Fig. 5b) on April $9^{\text {th }}$, started with a $60 \mathrm{~m}^{3}$ pulse which dropped to $20 \mathrm{~m}^{3} / \mathrm{s}$ in 3 days. Long recession of input flow resulted in long recessions of levels in P1 and P2. This is the only event when the levels at P3 are above those at $\mathrm{P} 2$. One could attribute this to the unknown recharge along the pathway between Kačna cave and Jama 1 v Kanjaducah.
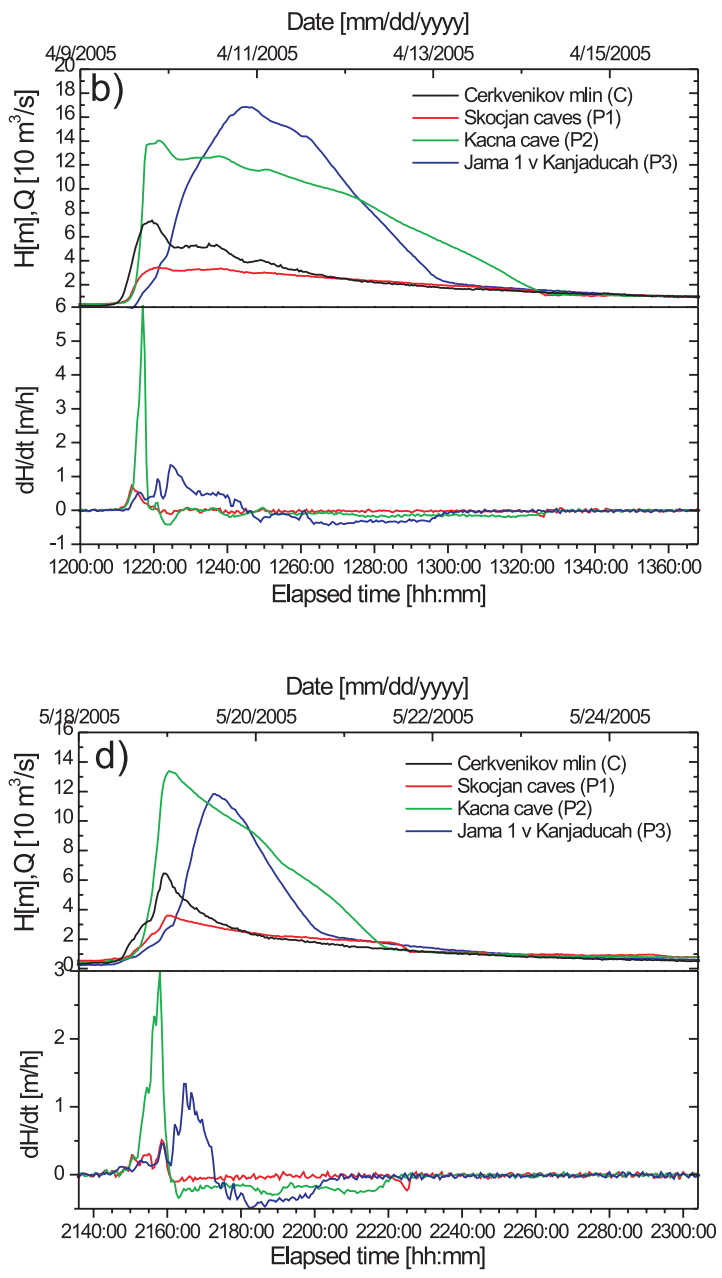

Fig. 5: The evolution of levels and level changes during for major flood events. Colour codes are valid for upper and lower graphs. 
Third event (Fig. 5c) on May $25^{\text {th }}$ was the largest. It comprises a single pulse with a maximum flow of 120 $\mathrm{m}^{3}$. The responds at $\mathrm{P} 1$ and $\mathrm{P} 2$ is vigorous. At $\mathrm{P} 2$ (Kačna cave) the rate of level rise reached $9 \mathrm{~m} / \mathrm{h}$. Maximum level at P1 (Škocjan caves) is $4 \mathrm{~m}$, at P2 $18 \mathrm{~m}$ and at P3 $14 \mathrm{~m}$. How undisturbed the flood wave passed the way to P2 can be seen from the kink in the rising limb of hydrograph which is nicely preserved in the level hydrograph at P2.

Fourth event (Fig. 5d) is similar but smaller compared to the third event and needs no further discussion at this point.

There were several small flood events following the dry period in August. One of them is shown in the Fig. 15. All levels show a sharp rise suggesting that the passage of the pulse through the system is little affected by the restrictions.

The next step we take is to plot our results versus input. Therefore, Fig. 6 presents the levels at all points in dependence on the flow rates at Cerkvenikov mlin. We shifted the levels back in time with respect to flow to consider the travel time between Cerkvenikov mlin and
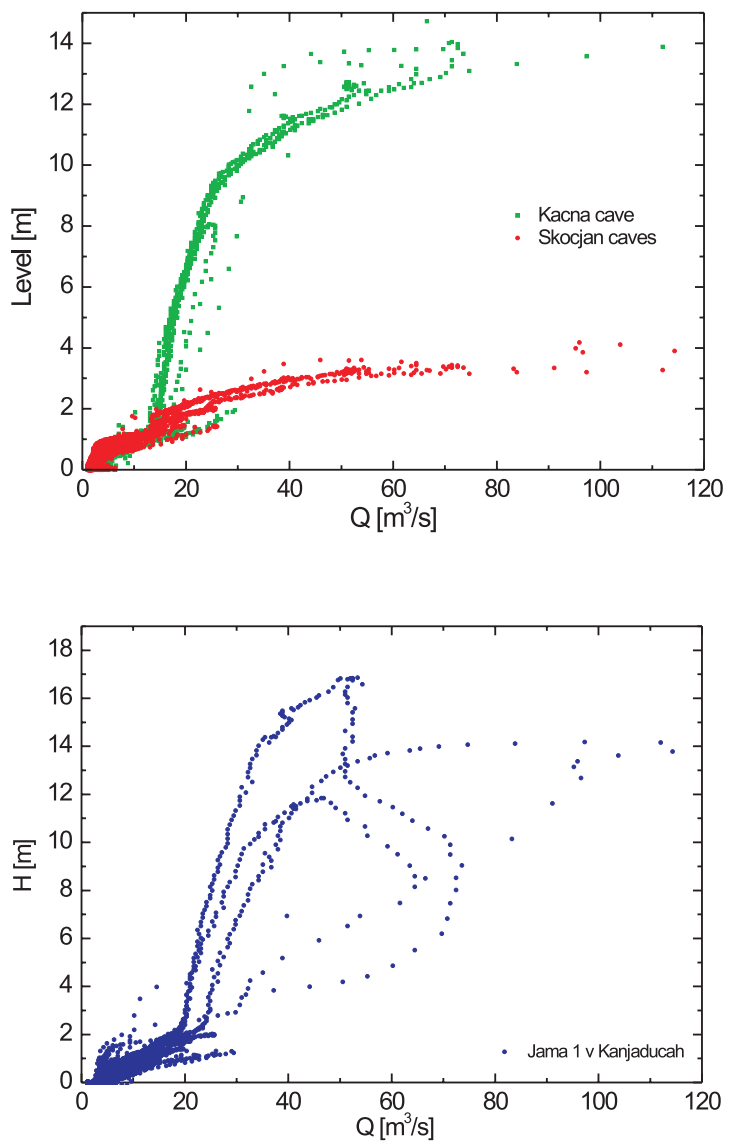

Fig. 6: Levels in Škocjan caves and Kačna cave (a) and Jama 1 v Kanjaducah (b) in dependence on the flow rates at Cerkvenikov mlin. particular measuring point. Therefore, the flow rates at time $t$ are plotted with the levels at time $t+T$, where $T$ is the average value given in the Tab. 1 . The choice is rather intuitive and although dubious for several reasons, the results are satisfactory for the first estimation.

Levels in Škocjan caves and Kačna cave show similar behavior below $10 \mathrm{~m}^{3} / \mathrm{s}$. The level rises as the recharge increases according to the relations valid for the open channel flow (Dingman, 2002). When the flow exceeds 15 $\mathrm{m}^{3} / \mathrm{s}$, the curve in Kačna cave deviates. We attribute this to the constrictions downstream from the P2 in Kačna cave, which becomes fully flooded when flow exceeds 15 $\mathrm{m}^{3} / \mathrm{s}$. Fig. 7 presents an extended elevation of the section of the Kačna cave which includes P2. Grey area gives the passage height which is $4-7 \mathrm{~m}$. The passage is about $15 \mathrm{~m}$ wide. Vertical scale above P2 shows levels, each bar representing $2 \mathrm{~m}$. Dotted line gives the level of P2.

To see what happens when part of the channel becomes completely flooded, we have employed a simple numerical model of sloping channel system with restrictions as shown on Fig. 8. A system of four rectangular channels, each $400 \mathrm{~m}$ long, $5 \mathrm{~m}$ wide is subjected to the water input from the left. Channel 1 and 3 are more than $50 \mathrm{~m}$ high, while channel 2 and 4 representing restrictions are 3 and $1.5 \mathrm{~m}$ high.

We used Storm Water Management Model (V.5) obtained from the US Environmental Protection Agency (http://www.epa.gov/ednnrmrl/models/swmm/index. $\mathrm{htm})$. The model allows calculations of flow and transport through the system of opened and closed channels as a response to a direct input or an input from the prescribed catchments area. One can apply static, kinematic or dynamic routing method and thus simulate many scenarios which are relevant for karst, when matrix flow could be neglected. The model has good potential for further indepth exploration of flood wave passage through a well developed karst system (Campbell \& Sullivan, 2002).

To a system presented on Fig 8 . we introduced linear increasing flow rates. The Q-H graphs at points $\mathrm{p}_{1}$ and $\mathrm{p}_{2}$ are presented on Fig. 9.

Initially an open channel flow exists along the whole domain (Fig. 8a). The relation between flow and level for a uniform flow in an open channel can be obtained from the Chezy equation (Dingman, 2002). Flow and level are related by the power law $\Delta h \propto Q Q^{n}$, where $n=6 / 10$ for a uniform rectangular channel (see Fig. 9). As the channel 4 becomes fully flooded (Fig. 8b) the level at $\mathrm{p}_{2}$ deviates. Now the mass balance at point $p_{2}$ in channel 3 requires

$$
A(H) \frac{d H}{d t}=Q_{\text {in }}(t)-Q_{\text {out }},
$$

where $H$ is the level, $A(H)$ is the area of water surface in the channel 3 and $Q_{i n}(t)$ is the inflow into the channel 


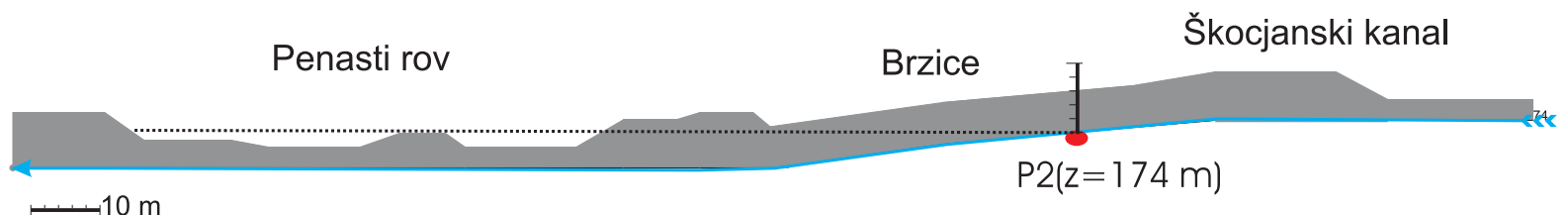

Fig. 7: Extended elevation of the section of Kačna cave that includes our measurement point. Grey area presents the channel height, dotted line the level of P2. Remapped from the original survey tables. (Source: Slovenian cave cadastre)
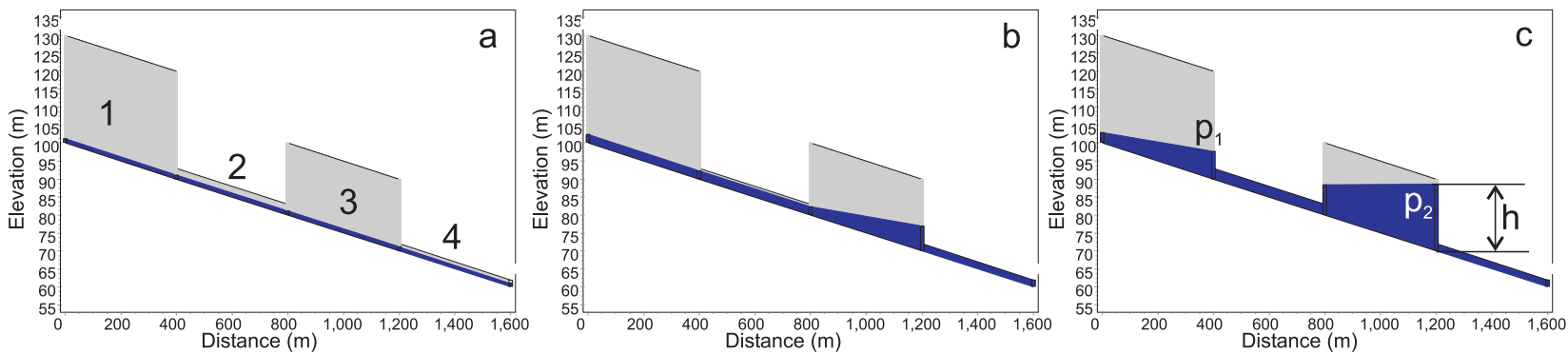

Fig. 8: System of sloping channels with restrictions. Restriction between points 4 and 5 is smaller than one between 2 and 3. A) Open channel flow is active along the whole domain. B) Restriction between points 4 and 5 is flooded. C) Both restrictions are flooded.

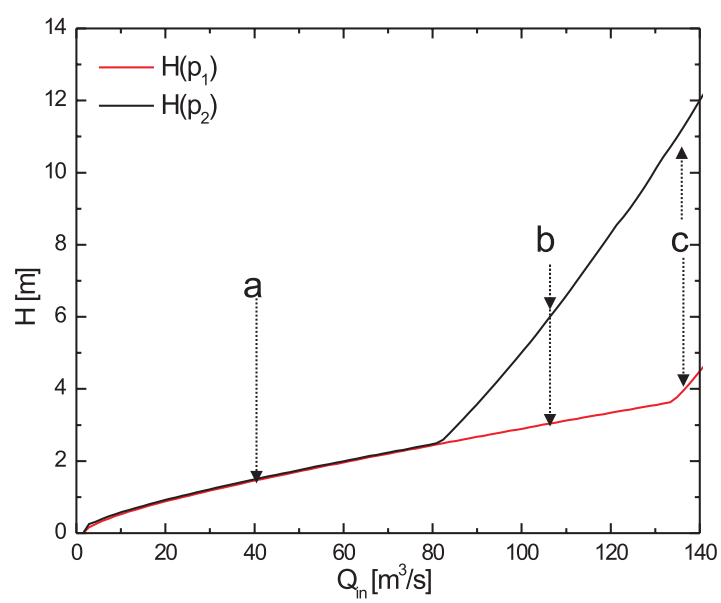

Fig. 9: Levels at points $p_{1}$ (red line) and $p_{2}$ (black line) in dependence on the input flow rates $Q$. Letters denote the situations $a, b$ and c presented on Fig. 8 .

3. $Q_{\text {out }}$ is the outflow to the channel 4 , given by DarcyWeisbach (Beek et al., 1999) equation

$$
\Delta H+\Delta z=\frac{f \cdot L}{2 g S^{2} d} Q_{\text {out }}{ }^{2}=k Q_{\text {out }}{ }^{2}
$$

$f$ is the friction factor, $\mathrm{L}$ the length of the conduit, $\mathrm{S}$ its cross-section, $d$ its hydraulic diameter and $g$ gravitational acceleration. $\Delta H$ is the difference between entrance and exit levels of channel 4 and $\Delta z$ the elevation difference between the two sides. Combining Eqs. 1 and 2 we get

$$
A \frac{d H(t)}{d t}+\frac{1}{\sqrt{k}} \sqrt{H(t)+\Delta z}=Q_{\text {in }}(t)
$$

Solution of Eq.3 gives the time dependence of the level, assuming that $Q_{i n}(t), k$ and $\mathrm{A}$ are known. For arbitrary input we can find numerical solutions. We present model results when a flood wave recorded at Cerkvenikov mlin on May $25^{\text {th }}$ (see Fig. 5) passes the system on the Fig. 8.

Fig. 10a presents the level hydrograph at $\mathrm{p}_{2}$ and the input flow hydrograph $Q_{i n}$, whilst Fig. 10b the flow-level curve. The dashed blue line on both figures denote the rising limb of the hydrograph.

The flow-level curve (Fig. 10b) exhibits a hysteresis which can be also observed on the flow-level curves of our real recorded hydrographs (Fig. 6), particularly for point P3, but also at $\mathrm{P} 2$. One reason is different location of flow and level hydrograph. Going downstream, the error we make by applying a constant time lag between the flow at Cerkvenikov mlin and the level at the station increases. We suspect that this is the main reason for the large areas of the hysteresis curves for Jama $1 \mathrm{v}$ Kanjaducah.

Another reason for the hysteretic behavior is flooding caused by restrictions. For an in-depth study of this behavior we would have to analyse the solutions of Eq. 3 , what we are not about to do. To demonstrate this we employ the even simpler model shown on Fig. 11. It comprise of a large $50 \mathrm{~m}$ high and $20 \mathrm{~m}$ wide channel ending with a $2 \mathrm{~m}$ high restriction of the same width. Input is at 

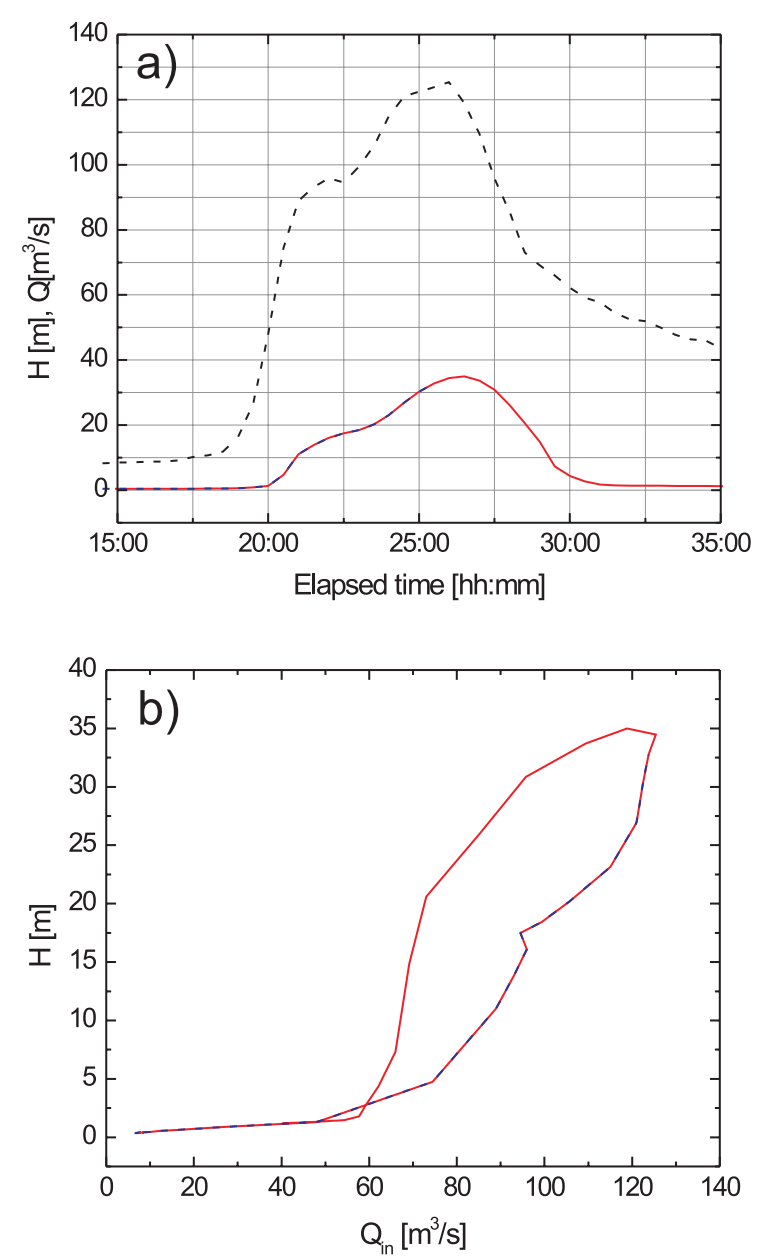

Fig. 10: Model results of the event (Fig. 5c) passing through the system on Fig. 8. a) Dashed line presents the input flow rates, full lines give the level hydrogram $h_{2}$ b) Flow-Level curve.

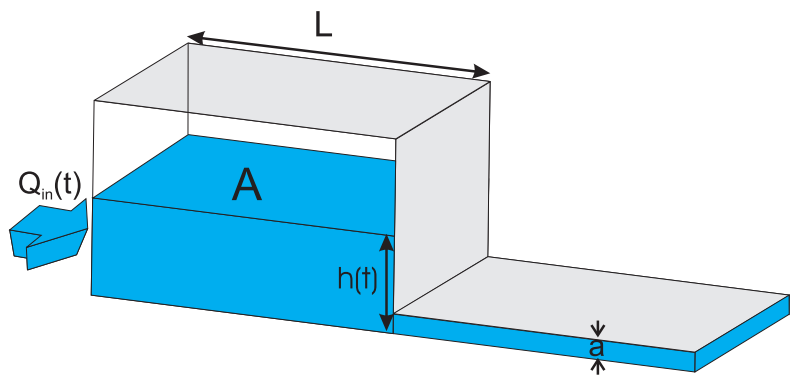

Fig. 11: Simple model of a large channel ending with restriction. The length of the entrance channel is $L, a$ is the height of the restriction, $A$ the surface area of the water prior to it and $Q_{i n}(t)$ the input flow hydrograph.

the left-hand side and increases linearly from 0 to 150 $\mathrm{m}^{3} / \mathrm{s}$ between $0-24$ hours and decreases linearly with the same slope during the second 24 hours.
The results are given in Figs. 12 and 13. Fig. 12a, presents the level response to a linear increase and drop of the flow rates (dashed line) for $\mathrm{L}=1 \mathrm{~km}$ and different
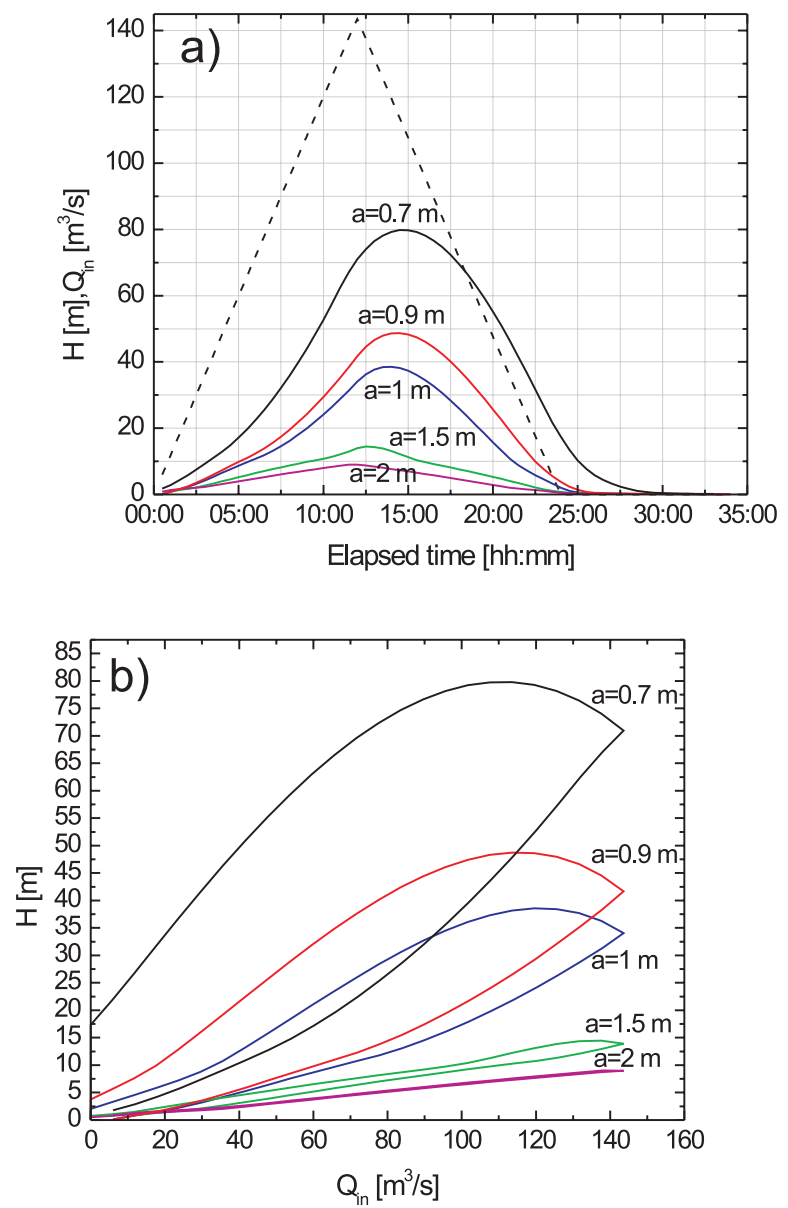

Fig. 12: a) Flow and level hydrographs for linearly increasing/ decreasing flood wave through the model given in Fig. 11.

$L=1 \mathrm{~km}$. Different lines present results for various apertures of restriction as denoted on the figure. b) Q-H plots for different restriction apertures.

heights of the restriction as given on the graph. For $a=2 \mathrm{~m}$ we see that the shape of level curve resembles that of the flow. As the height of the restriction decreases the flow through it is more and more inhibited and the level curves become distorted. Fig. 12b shows Q-H plots for these cases. The areas of the curves increase as the height of the restriction decreases.

Fig. 13 presents case where the restriction height is constant, but the length of the input channel changes from $1 \mathrm{~km}$ to $20 \mathrm{~km}$. The geometry of restriction is constant, with the height of $1 \mathrm{~m}$. The level curves now de- 

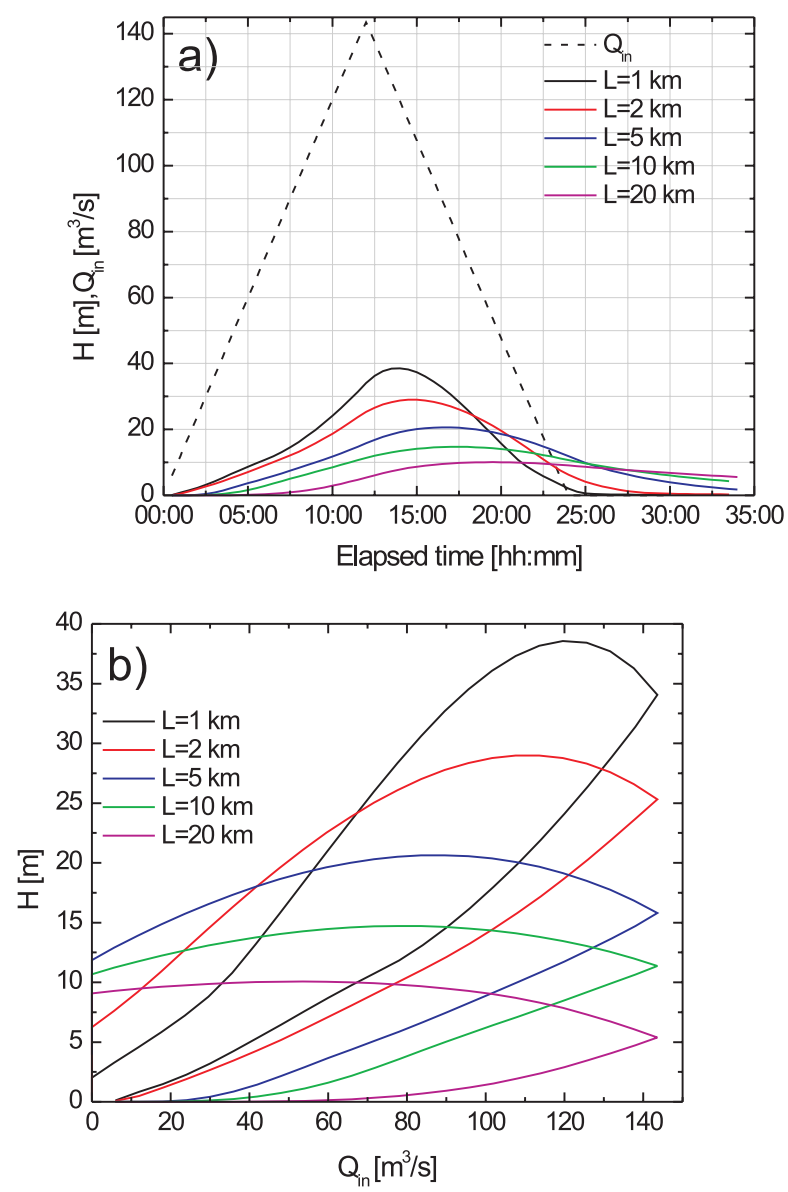

Fig. 13: a) Flow and level hydrographs for linearly increasing/ decreasing flood wave through the model given in Fig. 11. $a=1$ $m$. Lines present results for different lengths of the input channel as denoted on the figure. b) Q-H plots for different lengths of the input channel.

pend on the flow-restriction relation given by Eq. 3, and also on the distortion of the input flood wave due to its propagation in the open channel.

Even though the models give at least qualitative explanation of what might happen in the real system, the latter is (un)fortunately not as simple as that. Explorers have been following flow directions and flood remains in Kačna cave since the discovery of Reka in the cave back in 1972. There are many bypass and overflow passages, two of them just a few meters above and few meters below the P2, both joining together and leading to a system of galleries at a higher elevation. Based on the flotsam occurrence. Mihevc (2001) found that extreme floods in Kačna cave reach 130 meters above $\mathrm{P} 2$.
As the monitoring of flood waves continues it will be very interesting to observe the dynamics of floods that may be of a larger scale than those in 2005. In 2002 an instrument was put into Škocjan caves that measures the water level. It recorded floods reaching 40 meters, much larger compared to a 5-meter flood in the present monitoring. The fastest rise recorded in Škocjan caves was 9 $\mathrm{m} / \mathrm{h}$. Unfortunately no such measurements were conducted in Kačna cave before 2005, where much steeper rises may be expected. Environment Agency data show that the Reka river discharge varied largely at individual floods.

We analyzed seven flood pulses to estimate the velocity of their propagation through the observed system by taking the peak to peak distance of the level derivative, i.e. the points of the highest rising rate. Not all floods could be easily analysed this way, as the input hydrograph was rather complex. Results are presented in Tab.1.

\begin{tabular}{|r|r|l|l|r|}
\hline \multicolumn{1}{|l|}{ Date } & $\mathbf{Q}_{\max }\left[\mathbf{m}^{3} / \mathbf{s}\right]$ & $\begin{array}{l}\text { Time } \\
\text { C-P1 }[\mathbf{h}]\end{array}$ & $\begin{array}{l}\text { Time } \\
\text { C-P2 }[\mathbf{h}]\end{array}$ & $\begin{array}{l}\text { Time } \\
\text { C- P3 }[\mathbf{h}]\end{array}$ \\
\hline 27-Mar-05 & 15 & 2.5 & 3 & 6.3 \\
\hline 25-Apr-05 & 120 & 2 & 3.5 & 10 \\
\hline 1-Jul-05 & 19 & 2 & 2.5 & 5 \\
\hline 5-Jul-05 & 10.1 & 2.5 & 3.5 & 8 \\
\hline 7-Aug-05 & 10 & 3.5 & 4.5 & 9.5 \\
\hline 11-Aug-05 & 26 & 2.5 & 4 & 7.5 \\
\hline 29-Aug-05 & 19 & 2.5 & 3 & 5 \\
\hline \multicolumn{2}{|r|}{ Average travel time: } & 2.5 & 3.4 & 7.3 \\
\hline
\end{tabular}

Tab. 1: Travel times of selected flood pulses from the hydrograph at Cerkvenikov mlin (C) to Martelova dvorana in Škocjan caves (P1), brzice (rapids) in Kačna cave (P2) and terminate lake in Jama 1 v Kanjeducah (P3).

As can be seen from the table, about 2.5 hours is needed for the flood pulse to reach P1 in Škocjan caves, less than an hour more for P2 in Kačna cave and additional 4 hours for P3 in Jama $1 \mathrm{v}$ Kanjaducah. An interesting point is that there are no big variations in the speed along the way. Kačna cave, which is approximately on the half way between Cerkvenikov mlin (C) and Jama $1 \mathrm{v}$ Kanjaducah (P3) is also approximately at the half time of flood pulse travel between $\mathrm{C}$ and P3. 


\section{TEMPERATURES}

Temperature is a parameter which carries much information on hydraulic and thermal conditions in the karst interior (Genthon et al., 2005; Liedl et al., 1998). Water exchanges its temperature with surrounding rocks on its underground course. The heat flux is proportional to the temperature gradient normal to the water-rock boundary. Assuming a good mixing of water, the water-rock temperature difference should decrease exponentially with the length of its underground flow. The exponential factor is a function of flow rate, geometry of the channel and the normal temperature gradient.

Fig. 14 presents the temperature evolution during recession after a large flood event (see Fig. 5b). Daily tem-

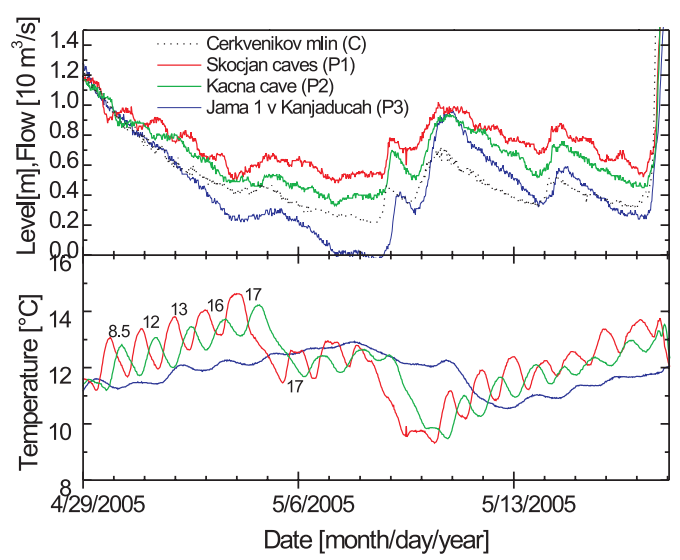

Fig 14: Flow, level and temperature following a flood event. Numbers at the temperature curves indicate peak to peak difference in hours between the temperatures at P1 and P2.

perature oscillation at Kačna cave follows that of Škocjan cave, but its amplitude progressively decreases as the flow rates drop and the peak to peak distance increases. Oscillations at $\mathrm{P} 3$ are hardly observed and vanish when the flow is low enough (e.g. smaller than $0.5 \mathrm{~m}^{3} / \mathrm{s}$ ).

Further data and analysis are needed to understand the temperature dynamics upon arrival of the flood pulses. Nevertheless, we see from Fig. 15 that the levels and temperatures respond simultaneously to a small event on August $11^{\text {th }}$.

Along completely flooded parts the level signal is pressure transferred, and therefore faster than the temperature signal. Simultaneous arrivals of both signals show the absence of such segments, leading to a conclusion that an open surface flow of Reka along most of the

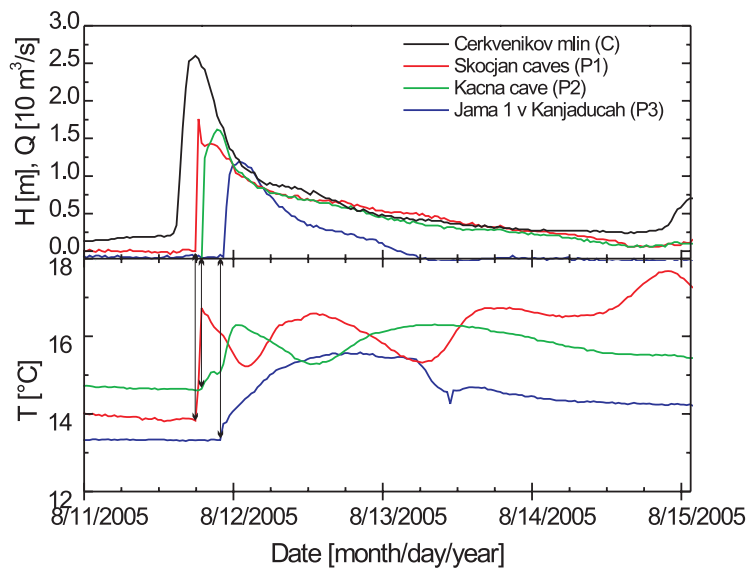

Fig. 15: Level and temperature responds to a small flood event following a period of dry conditions.

way could be expected at least for event of comparable scales.

\section{CONCLUSION AND FURTHER PERSPECTIVES}

The intention of this paper was to present the first results; therefore conclusion will be rather short. There is a fast passage of a flood wave through the presented part of the system. To give the relation between the travel time of the water parcel and that of the flood pulse further data and analysis are required. Nevertheless some data indicate that the these times are similar at least for small flood events (see Fig. 15). During low flow, travel times become order of magnitude larger (Fig. 14). From the passage of flood waves through the system we anticipate a (continu- ous) system of large conduits also in the parts which are inaccessible at the moment.

Many assumptions are still to be proved. Data are being recorded at all measuring points. Valuable sets of data is expected from Brezno v Stršinkni dolini and caves on the Italian side of the plateau, which are located in the area where the gradient becomes practically flat.

Further actions include in-depth time series analysis, integration of precipitation data, dye tracing of main Reka flow with field fluorimeters positioned in caves and 
further numerical modelling of events passing through the conduit-restriction systems with open channel and pressure flow.

Flooding could be an important factor for the genesis of large voids in the studied caves (Mihevc, 2001).
Large oscillations of water levels could be important if not crucial factor for the genesis of large voids like sub/ vertical galleries in Jama $1 \mathrm{v}$ Kanjaducah and Brezno v Stršinkni dolini and Lindner's hall in Grotta di Trebiciano.

\section{ACKNOWLEDGMNETS}

This research would not be possible without an invaluable work of generations of cavers in all investigated cave. Thanks to cavers from Divača and Sežana for the help with our work. The study has been supported by the In- terreg project "Monitoring of the underground flow of reka Reka" (Vzpostavitev monitoringa podzemnega toka Reke).

\section{REFERENCES}

Beek, W. J., Muttzall, K. M. K., \&Van Heuven, J. W., 1999: Transport phenomena. John Wiley \& Sons, 329 pp, Chichester, New York.

Brilly, M., Mikoš, M., Petkovšek, G., Šraj, M., Kogovšek, J., Drobne, D., \& Štravs, L., 2002: The experimental monitoring of water regime in the Reka river.- Acta carsologica, 31, 65-74, Ljubljana.

Campbell, C. W.Sullivan, S. M., 2002: Simulating timevarying cave flow and water levels using the Storm Water Management Model.- Engineering Geology, 65, 133-139.

Cucchi, F.Zinni, L., 2002: Underground Timavo river monitoring.- Acta carsologica, 31, 75-84, Ljubljana.

Cucchi, F., Forti, P., Marinetti, E., \&Zinni, L., 2000: Recent developments in knowledge of the hydrogeology of the classical karst.- Acta carsologica, 29, 5578, Ljubljana.

Dingman, S. L., 2002: Physical hydrology. Prentice Hall, 646 pp, Upper Saddle River, N.J.
Ford, D.C.Ewers, R., 1978: The development of limestone caves in the dimensions of length and depth.- Canadian Journal of Earth Sciences, 15, 1783-1798.

Galli, M., 1999: Il Timavo, esplorazioni e studi. Vol. 23, Atti e Mem. Comm. Grotte "E. Boegan", Società Alpina delle Giulie, 195 pp, Trieste.

Genthon, P., Bataille, A., Fromant, A., D'Hulst, D., \& Bourges, F., 2005: Temperature as a marker for karstic waters hydrodynamics. Inferences from 1 year recording at La Peyrere cave (Ariège, France).Journal of Hydrology, 311, 157-171.

Kranjc, A., Ed., 1997: Slovene Classical Karst - "Kras". ZRC Publishing, $321 \mathrm{pp}$.

Liedl, R., Renner, S., \& Sauter, M., 1998: Obtaining information about fracture geometry from heat flow data in karst systems. In: Jeannin, P.-Y.\& Sauter, M.(Ed.): Modelling in karst systems, Université de Neuchâtel, 143-157.

Mihevc, A., 2001: Speleogeneza Divaškega krasa. Vol. 27, ZRC, ZRC Publishing, 180 pp, Ljubljana. 
